\title{
Competitive Investorism: Governance of Market Infrastructure Institutions and their Social Responsibility
}

\author{
K.V. Bhanu Murthy *
}

\begin{abstract}
There has been an on-going debate over the Market Infrastructure Institutions (MIIs): their number and growth, as well as, the need for regulation and governance of MIIs, including stock exchanges (Lee (2010)). This paper raises a set of questions: (i) What is the economic understanding of governance of MIIs?, (ii) What is its role in developing competitive financial markets?, and (iii) What are the implications for investors? The Bimal Jalan Committee (2010) for the reform of MIIs fails to recognise the real issues in bringing about stock market reforms. It ignores the need for competition and dynamics amongst the MIIs. Apart from such a need, there is the larger interest that stock markets should serve: that of investors. A necessary condition for 'competitive investorism' to happen is the establishment of new Market Infrastructure Institutions, especially stock exchanges that are for-profit and are cross-listed. Cross-listing brings market discipline and may go beyond regulatory control by doing well for stock markets and investors alike. It makes stock markets competitive and efficient and passes on these benefits to the investors.
\end{abstract}

Keywords: Competitive Investorism, Market Infrastructure Institutions, Bimal Jalan and Kania Committee.

\subsection{Introduction}

A recent debate has arisen about the Governance of Market Infrastructure Institutions (MIIs) both in India and across the globe. The major standpoint at the global level has been put up by Lee (2010). In the introductory chapter, Lee states the following position: "The governance of infrastructure institutions in the financial markets has become a matter of significant commercial, regulatory, legislative, and even political concern. They play a fundamental role in ensuring the efficiency, safety, and soundness of financial markets globally and more generally in furthering economic development.

*Professor, Department of Commerce, Delhi School of Economics, University of Delhi. 
The manner in which market infrastructure institutions are governed critically affects their performance. There is great debate, however, both about how they are governed and about how they should be governed". (Lee, 2010; p. 1.)

Lee argues that governance is about power. The three questions he poses are:

- Who has what power at such institutions?

- How and why do they obtain it?

- How and why do they exercise it?

Further, the understanding in respect of governance of MIIs is that these questions are determined largely 'by the formal, legal, and regulatory constructs within which it operates'. The attributes associated with corporate governance are: its corporate status and mandate, its ownership structure, the composition and role of its board, the role of its management, etc. The whole gamut of factors that govern MIIs are treated as a legal construct that revolves around contractual arrangements and their regulatory status. It is also felt that in addition, 'a range of informal, non-constitutional, and non-contractual factors may affect an institution's governance, such as the historical, cultural, and political framework within which it operates'.

This paper raises a different set of questions:

1. What is the economic understanding of governance of MIIs?

2. What is its role in developing competitive financial markets?

3. What are the implications for investors?

This paper places in perspective the debate in relation to the above three aspects of the Governance of Market Infrastructure Institutions.

The layout of the paper is as follows: Section 1sets the ball rolling; in Section 2, the background is laid out; the third section is about MII regulation in India; section 4 tells us about investors' interest; the last section gives concluding remarks.

\subsection{Background}

Stock exchanges offer a host of services to listing companies. These include:

(i) liquidity, (ii) execution of services, (iii) signaling function for listed companies, (iv) monitoring of trading to prevent manipulation and insider trading, (v) standard rules to reduce transaction costs, and (vi) clearing of buy and order transactions. Traditionally, stock exchanges operating as a "club of brokers" offered these services as monopoly operators serving largely under a mutual governance structure. The members of the club enjoyed rights of ownership, decision-making (one member, one vote), and trading. Value enhancement of the exchange was achieved by restricting access. Stock exchanges 
are now increasingly changing their business model and restructuring themselves across the world due to the simultaneous convergence of a number of powerful developments. There has been a debate about the growth and regulation of financial markets. One question is whether one shoe fits all. Historically, there have been many differences amongst different countries and continents. So, it is obvious that there is no single model that fits all. In the case of large Latin American countries the stock exchanges actually came up much before the regulatory bodies even came into existence. This made the relationship between the two bodies very difficult.

A much debated issue is about whether government regulation may dampen market development. A related question has been about the optimal number of stock exchanges that a country can afford. A number of small developing economies like Bangladesh, Chile and Pakistan have more than one stock exchange. This shows that healthy competition is good for their economies. Competition leads to lower trading fees and greater innovation. On the other hand, it is argued that too many stock exchanges would lead to heavy overhead costs. The regulatory and infrastructure costs may also escalate unduly. It has also been argued that liquidity would be thinly spread out. Another argument is that if the regulator is weak, as may be the case with developing countries, then one stock exchange may undermine the other. This could lead to 'race to the bottom' competition. There have been all kinds of experiences. In the case of Korea it has been seen that a stock exchange that was set-up by the government has slowly become independent and is also making profits.

This brings us to the question of whether stock exchanges should pursue profit motive or not. It has also been argued that in the cases of low income countries the regulator would have lower power of oversight, lack of resources and lack of authority. There has been a keen debate about what is considered to be self-regulatory (Carson, 2003). Those who believe that MIIs must be solely profit driven feel that it would be useless to regulate.

At another level it is argued that unless the 'cartel' of broker-owners is broken the markets would not develop. This brings us to the question of demutualization (Calcutta Stock Exchange, 2003). "Demutualization involves the conversion of a member-owned and member-governed entity into a for-profit shareholder-owned corporation. This progressive measure enhances the capacity for exchanges to conduct orderly and efficient markets by providing them with more access to capital and improved regulation. Demutualization can also assist an exchange's efforts to be more competitive in an environment of merging exchanges, strategic alliances and electronically based trading systems." (Akhtar, 2002). 


\subsection{Regulation and Competition in India}

The Finance Minister in his Budget Speech for the year 2002-03, announced for Corporatization and Demutualization of Stock Exchanges by which ownership and trading right would be separated from each other. To implement the said policy of the Government, Securities and Exchange Board of India constituted a group under the Chairmanship of former Chief Justice of India, Sri M.H. Kania and the recommendation of the group were as follows:

- The three stakeholders viz. shareholders, brokers and investing public through the regulatory body should be equally represented on the governing board of the demutualized stock exchange;

- There should be specific vacancies on the board for each group of stakeholders;

- The shareholders' representatives should not be functioning brokers;

- The brokers' representatives would be elected by the shareholders from among the brokers of the stock exchange.

A committee of experts under the chairmanship of former Reserve Bank of India Governor Bimal Jalan and comprising seasoned capital market and finance professionals was asked to review the ownership and working of market infrastructure institutions. Its report, was submitted to the Securities and Exchange Board of India on 22 November 2010, effectively raises the bar for existing institutions and prospective entrants.

The three market infrastructure institutions are:

- The stock exchanges (NSE and BSE);

- The clearing corporations (CCIL); and

- The depositories (NSDL \& CSDL).

In the reform era, it is the stock exchanges that have seen the most visible transformation. They have also attracted the maximum regulation. The other two, though playing a vital role in the capital market edifice, are in a sense adjunct to the stock exchanges. The recommendations of Bimal Jalan Committee included the following:

- No listing (cross-listing) of stock exchanges

- Anchor Investors restricted to Banks, PFIs.

- Optimal Number of Exchanges in India.

- Cap on Profits

There is another topical reason why the Committee's recommendations on stock exchanges have attracted so much interest. There have been plans by newer players to start an exchange. An attempt by MCX, a commodities exchange, to start a stock exchange has been thwarted by the regulator. If the panel's recommendations are 
accepted, the doors will be practically shut for many new parties. United Stock Exchange which is Public-Private Partnership is another example. Both of these are having only currency futures.

The Committee report has, as its core recommendation, the provision that only banks, insurance companies and domestic public financial institutions with a net worth of Rs.1,000 crore be anchor investors in a stock exchange, a position analogous to but not identical with promoters. The panel wants a widespread dispersal of shareholding in a stock exchange. These two provisions - of allowing only well capitalized parties as anchor investors and ensuring a dispersal of shareholding — are deemed necessary for the proper functioning of an exchange. They also rule out control by any one party. An anchor investor can hold 24 per cent of the share capital but should bring it down to 15 per cent within ten years.

Stock exchanges will not be allowed to list. This important provision should put an end to all controversies that will arise if stock exchanges list with one another (crosslisting). Perhaps even more significantly the provision reinforces what seems to be the thrust of the committee's recommendation: that the business of a stock exchange should neither yield large profits nor be a magnet for speculative capital. A SEBI-appointed committee today opposed listing of stock exchanges on bourses arguing that any downward movement of their share prices could hit the credibility of the market institutions. (Business Line (2010), Business Line (2012) and Business Standard (2010)).

The recommendation of the Bimal Jalan Committee, if accepted, would derail the plans of the country's two premier bourses -- the Bombay Stock Exchange (BSE) and the National Stock Exchange (NSE), to go public. "Market infrastructure institutions (MIIs) being public institutions, any downward movement in its share prices may lead to a loss of credibility and this may be detrimental to the market as a whole. Therefore, the Committee is not in favor of permitting listing of MIIs," said the report on which Securities and Exchange Board of India (SEBI) has invited comments from the public by December 31.

Many foreign investors had picked up equity in India's oldest stock exchange BSE in the hope that its shares would be listed on stock markets. In August last, billionaire investor George Soros had picked up a 4 per cent stake in BSE for USD 35 million. Soros' Quantum hedge fund bought the stake from Dubai Financial, a part of state-run Dubai Holdings, for an estimated Rs. 380 per share. In February-March 2007, Deutsche Boerse AG and Singapore Exchange Ltd acquired 4.98 per cent each of BSE's stake at the time when the exchange was demutualized. Foreign investors now hold 30 per cent stake in BSE, lower than the permissible limit of 49 per cent. The Jalan committee, which submitted its proposals after months of deliberations, also said that disclosure and 
corporate governance norms for market institutions should be the same as that applicable for listed entities. In case of companies wherein stock exchanges hold 24 per cent or more, that entity would have to seek prior nod of the Securities and Exchange Board of India (SEBI), the market regulator.

The provision of preventing listing will dry up funding into new-generation, state-ofthe art exchanges as these require huge capital in infrastructure, technology, human resources, etc. Not only the exchanges in developed markets such as New York, Canada and Tokyo, even small exchanges in emerging markets such as Dubai, Malaysia and Africa are listed. So barring listing in India will not drive global alignment of India's financial market. Bombay Stock Exchange and MCX-SX have gone public with their view that they support listing and it is only National Stock Exchange (NSE) has always opposed listing.

Sharma and Jain (2002) mention that "the cross-listing of stock exchanges would effectively counter the 'conflict of interest' arising out of self-listing". Some observers have suggested proposals such as mandatory dual listing for stock exchanges to take care of conflict of interest (Fleckner, 2006). NSE has always shirked public scrutiny in the past by escaping being answerable to the RTI. It is not a transparent exchange but a private kingdom as it is $67 \%$ controlled by private and foreign players, reaping monopolistic profits, killing competition. NSE goes past the policy makers due to its monopoly and making them believe there is no other alternative, for its own benefit.

How can Corporate Governance (CG) norms be applied if stock exchanges are not allowed to be listed? In 2003 SEBI came out with CG norms for listed companies. "The Stock Exchanges shall ensure that all provisions of corporate governance have been complied with by the company seeking listing for the first time, before granting any new listing. For this purpose, it will be satisfactory compliance if these companies have set up the Boards and constituted committees such as Audit Committee, shareholders/ investors grievances committee, etc. before seeking listing. (SEBI/MRD/SE/31/2003/26/08 August 26, 2003)."

The concept of having banks and public financial investors as 'Anchor Investor' is nothing new as they always had the right to ownership in an exchange. Earlier, Banks and PFIs were allowed to hold 5\% in the stock exchange, which was revised up to $15 \%$ following the recommendations by SEBI's Kania Committee. The Bimal Jalan Committee only raises this limit to $24 \%$. Stock exchanges are not the first line of business for public financial institutions and banks. Whenever they have invested in exchanges, they have always remained as passive investors. So, it can be assumed that in future too, banks and PFIs will also not actively partake in this industry as this is not their core line of business. So this recommendation does not support BJC's reason for 
choosing banks and PFIs as anchor investors as those "who will take the lead role of setting up a stock exchange." This recommendation is designed to benefit the existing shareholders of NSE. For the reason indicated by the BJC, if RBI had decided that future banks can have only Banks and Financial Institutions as anchor shareholders would we have ever seen a new bank or any product differentiation if existing banks had promoted ICICI, HDFC, AXIS Bank etc.?

While the Committee states 'It is desirable to ensure that fair competition is available to avoid perverse monopoly,' yet, is of the opinion that the optimal number of exchanges required in India cannot be arrived at with any degree of precision. However, here is a Regulator, which, though speaks of favouring competition, but is actually complacent with running only two equity exchanges, two depositories and a standalone clearing corporation. SEBI has never considered gaps in India's under-penetrated market and underdeveloped products serious enough reasons to put a change in place. The recommendation is self-contradictory as the Committee on one hand talks of being in favour of competition, also believes "large number of stock exchanges will fragment liquidity" though there are examples of very liquid markets globally that also have lot many more exchanges, such as in US and the Europe.

This indecision and along with other recommendations that would deter investors from setting up new-generation exchanges in India would hamper global alignment of India's financial markets and also cause a big blow to India's rise as the global financial hub of the East as our financial markets will continue to be ruled by a monopolistic exchange (NSE) with no investments in product innovation, financial literacy and technology. "The MII being a public utility should endeavor to earn only reasonable profits at par with average earnings of the corporate sector in India," states the Committee. This is in spite of the blatant fact that NSE makes a profit of $70 \%$, which is very high, by all standards.

The Committee has Members who have vested interest and conflict of Interest. This is the reason behind the committee's motive to benefit NSE and also a further proof of regulatory capture. In the 7-member committee, there is a representative of the Tata Group. It should be noted that Tata Consultancy Services of the Tata group is the largest vendor on NSE. Another Member, Mr. KP Krishnan, is a well-known lobbyist for NSE who had advised NSE on its sale of stake in NCDEX to LIC and NABARD. Uday Kotak runs a bank, a broking outfit and a Mutual Fund, which are regulated entities under SEBI and NSE.

It may be noted that the Kania Committee had no SEBI member on it and had well-known members from the judiciary, accountancy, broking, Income Tax and Department of Company Affairs, whereas the current committee had 3 members from 
SEBI and its associate agencies. From all of the above, it is amply clear that NJC is anticompetitive:

- It clearly is favoring NSE

- It is favoring monopoly

- Its composition is biased

- It smacks of duality

Having critically discussed Jalan Committee on MIIs, we now take on a related aspect of investor protection.

\subsection{Investors' Interest}

We now discuss the aspect related to investor protection. There could be three approaches to investor protection that have been discussed below.

\subsection{Grievance redressal}

The salient features of SCORES (SEBI Complaints Redress System) are:

- SCORES is web enabled and provides online access $24 \times 7$.

- Complaints and reminders thereon can be lodged online at the above website at anytime from anywhere.

- An email is generated instantaneously acknowledging the receipt of complaint and allotting a unique complaint registration number to the complainant for future reference and tracking.

- The complaint forwarded online to the entity concerned for its redressal.

- The entity concerned uploads an Action Taken Report (ATR) on the complaint.

- SEBI peruses the ATR and closes the complaint if it is satisfied that the complaint has been redressed adequately.

- The concerned investor can view the status of the complaint online from the above website by logging in the unique complaint registration number.

- The entity concerned and the concerned investor can seek and provide clarification on his complaint online to each other.

- Every complaint has an audit trail and all the complaints are saved in a central database which generates relevant MIS reports to enable SEBI to take appropriate policy decisions and or remedial actions, if any.

\subsection{Investor Education}

- Educating and empowering, 
- Decision facilitating,

- Advisor advice validating,

- Safety protection enhancing,

- Fairer play / field levelling, and

- Governance building

The above two approaches are existing approaches to investor protection. Next, we take up a new approach that is neither regulatory nor legal. It is based on market conditions.

\subsection{Investor Welfare}

This is a new concept that demands attention has been projected by Hubbard (2010). In his recent book used the term 'Investor Welfare' (or Investorism). This concept is in line with 'consumerism' which highlights consumer welfare. Just as consumer markets are beset with consumer issues and desire consumer protection, the phenomenon of investorism involves investor issue and investor protection.

The attributes of 'investorism' are essentially economic. Given below are some of the dimensions:

1. Charging excessive fees from retail investors;

2. Existence of price differentials which represent inefficient pricing of assets;

3. Monopolistic tendencies; and

4. Economies of scale not being passed-on to investors.

The claim to the terms "investor welfare" is that of Hubbard (2003). But, we wish to lend a new connotation to the terms so as to distinguish it from the ordinary terms of grievance redressal and investor awareness. The basic question is: Whose welfare lies at the root of the Capital Market? The artificial entity that is called the Company, that raise money or is it the retail investor who invests money? It is obvious that the investor needs to get welfare gains. Accordingly, the new connotation in this context is investorism. The next question is as to how this can happen: Only with the help of the markets. It is only possible by having efficient markets. This raises cascading questions:

1. Do efficient markets exist? Or do they have any mechanism?

2. How do they evolve?

- Through competition.

3. How does competition take place?

- By having more stock exchanges.

4. How to reduce supernormal profits now afforded by a monopoly stock exchange NSE?

- By having more stock exchanges. 
50 | MUDRA: Journal of Finance and Accounting, Vol. 2, Issue 1

5. Stock exchanges have a corporate responsibility towards investors.

- How can this be ensured?

6. By better Corporate Governance norms for stock exchanges.

- How can this be done?

7. By bringing them under the purview of CG norms in the listing agreement.

Finally, with competition stock exchanges will strive to serve the investor better. Also by having more, better and more responsible stock exchanges frauds will be less.

"The movement of money away from purchasing goods and services ("consumerism") towards investing in mutual funds, stocks, and other financial assets. (is called 'investorism')," (http://www.wordspy.com/words/investorism.asp). In this context, we have coined a new term called - "Competitive Investorism", defined as: "The movement of income away from purchasing goods and services (consumerism) towards investing in mutual funds, stocks, and other financial assets that happens due to market development and market efficiency, is called "competitive investorism."

\subsection{Conclusion}

There has been an on-going debate over the need for regulation and governance of the Market Infrastructure Institutions. The Bimal Jalan Committee (2010) for the reform of Market Infrastructure Institutions ignores the need for competition and dynamics amongst the MIIs. Apart from such a need, there is the larger interest that stock markets should serve: that of investors. A necessary condition for 'competitive investorism' to happen is the establishment of new Market Infrastructure Institutions, especially stock exchanges that are for-profit and are cross-listed. Cross-listing brings market discipline and makes stock markets competitive and efficient. These benefits are then passed on to the investors.

\section{References}

Akhtar, S. (2002). Demutualization of Stock Exchanges: Problems, Solutions and Case Studies. (Ed.).Asian Development Bank, Manila.

Business Line (2010). Not yet time to list stock exchanges: Jalan, December 22, 2010, p.1.

Business Line (2012). SEBI allows stock exchanges to list, but with riders, April 3, p. 1. 
Business Standard. (2010). Jalan: Door not closed on listing of bourses, $22^{\text {nd }}$ December, p. 1 .

Calcutta Stock Exchange (2003). Scheme for Demutualization. Available at: www.cseindia.com/new_web/csedmuscheme.php

Carson, J.W. (2003). Conflicts of Interest in Self-Regulation: Can Demutualized Exchanges Successfully Manage Them? World Bank Policy Research Working Paper No. 3183. http://papers.ssrn.com/sol3/papers.cfm?abstract_id=636602

Fleckner, Andreas M. (2006). Stock Exchanges at the Crossroads. Fordham Law Review, 74.

Hubbard, Glen. (2010). Mutual Fund Industry: Competition and Investor Welfare, Columbia University Press: New York.

Jalan, Bimal. (2010). Review of ownership and governance of market infrastructure Institutions (MIIs). www.sebi.gov.in/cms/sebi_data/attachdocs/1288255751737.pdf

Lee, Ruben. (2010). Running the Worlds Markets: The Governance of Financial Infrastructure. Princeton University Press: Princeton.

Narasimham, T.E. (2011). Address exchanges' dual role, says NSE Chairman Kelkar. Business Standard, $7^{\text {th }}$ April, p. 3.

Press Trust of India (2010). SEBI committee against listing of stock exchanges on bourses. November 23, p.1.

SEBI (2003). Corporate Governance in listed Companies - Clause 49 of the Listing Agreement. http://www.sebi.gov.in/circulars/2003/cir2803.html

Sharma \& Jain. (2002). Cross listing of stock exchanges: strengthening self-regulation? National Law University, Jodhpur. 